\title{
KONFRONTASI REPUBLIK INDONESIA DENGAN MILITER JEPANG MENJELANG MASUKNYA SEKUTU 1945-1946
}

\section{CONFRONTATION OF INDONESIA REPUBLIC WITH JAPANESE MILITARY AHEAD OF THE ENTRY OF THE ALLIES 1945-1946}

\author{
M. Halwi Dahlan \\ Balai Pelestarian Nilai Budaya Jawa Barat \\ Jln. Cinambo No. 136 Ujungberung-Bandung \\ e-mail: karaengalwi@gmail.com
}

\begin{abstract}
Abstrak
Perlawanan pejuang (laskar, BKR kemudian TKR) dengan militer Jepang di Indonesia ditandai dengan peristiwa perlucutan senjata oleh pejuang tersebut. Berbagai insiden terjadi disebabkan baru saja Jepang memperlihatkan sikap tegas dalam menjajah, tiba-tiba semua berubah dengan sikap menyerah kepada Sekutu. Bagi Indonesia kondisi ini sebenarnya merupakan peluang untuk melengkapi diri dari segi peralatan perang yang akan menjadi aset bagi pasukan perangnya. Tetapi hal itu menjadi sulit karena sesuai aturan hukum perang internasional tentang tawanan perang, selain pasukan Jepang turut diserahkan seluruh peralatan perangnya. Beberapa daerah sempat menerima atau pun merampas persenjataan tersebut, namun kemudian direbut kembali oleh Militer Jepang. Militer Jepang yang mempertahankan senjata mereka dan patuh pada konvensi Jenewa 1929, berhadapan dengan semangat kemerdekaan dari seluruh rakyat Indonesia. Di Jawa Barat insiden perlucutan senjata tersebut sempat terjadi tetapi tidak meluas, berbeda dengan di Jawa Timur yang hampir seluruh pejuangnya memiliki senjata rampasan. Perbedaan tersebut ternyata terletak pada lambatnya informasi yang sampai dari pemerintah pusat kepada pemerintah daerah.Jawa Barat diuntungkan karena jaraknya yang relatif dekat dengan Jakarta sehingga dengan cepat pemerintah daerah dan pimpinan BKR/TKR dapat mengkonsolidasi anggota pasukannya. Penulisan ini menggunakan metode kepustakaan dan historiografi yang dihasilkan bersifat deskriptif analisis. Untuk mendukung penulisan ini digunakan teori konfrontasi.
\end{abstract}

Kata kunci: Konfrontasi, pejuang, Indonesia, Jepang, Sejarah.

\section{Abstract}

The resistance of fighters (paramilitary troops, BKR then the TKR) with the Japanese military in Indonesia was marked by events of disarmament by fighters. Various incident occurred just due to Japan showed a firm stance in colonizing, suddenly all changed with the attitude of surrender to the Allies. For Indonesia, this condition was actually an opportunity to equip themselves in terms of armaments that became an asset to the troops for war. But it was difficult because according to the rules of international law concerning prisoners of war, not only Japanese forces but also entirety of the war equipment were also should be handed. Some areas could receive or seize such weapons, but was later recaptured by the Japanese military. Japanese military retained their weapons and abided by the 1929 Geneva Convention, dealing with the spirit of independence of the entire people of Indonesia. In West Java, the disarmament incident had occurred but did not extend, unlike in East Java, where nearly all of the fighters had looted weapons. The difference lied in the slow of turning up information from central government to the regions. West Java had benefit because it was relatively close to the Jakarta, so the local government and the leadership of BKR / TKR could quickly consolidate the fighters. This study uses literature and historiography that produces a descriptive analysis. To support this study, the theory of confrontation is used.

Keywords: Confrontation, fighters, Indonesia, Japan, History. 


\section{A. PENDAHULUAN}

Jatuhnya wilayah Hindia Belanda akibat pergerakan pasukan militer Jepang dimulai dari dikuasainya Kepulauan Tambelan di Laut Cina Selatan pada 27 Desember 1941, selanjutnya berturut-turut Tarakan dan Manado pada 11 Januari 1942, Balikpapan 24 Januari 1942, Ambon 2 Februari 1942, Makassar 9 Februari 1942, Palembang 15 Februari 1942, Timor 20 Februari 1942, Banten 1 Maret 1942, dan Batavia sebagai pusat pemerintahan Hindia Belanda dikuasai pada 5 Maret 1942, Sumatera Utara dan Sabang 12 Maret 1942, Padang 17 Maret 1942, Fakfak 1 April 1942, Sorong 4 April 1942, Ternate 7 April 1942, Jayapura 19 April 1942, (Banda Neira, Pulau Buru, Kepulauan Sula, Lombok, dan Flores pada Mei 1942), Kepulauan Natuna Juni 1942, (Kepulauan Tanimbar, Kepulauan Key, dan Kepulauan Aru pada Juli 1942), Sunda Kecil (Nusa Tenggara Timur) September 1942, hampir seluruh Papua kecuali Merauke pada Desember 1942 (Wenri Wanhar, 2014, 110-112). Jadi negara kecil seperti Jepang dengan kekuatan militernya hanya membutuhkan waktu \pm 3 bulan untuk menganeksasi dan menguasai pusat pemerintahan Hindia Belanda di Batavia, dan 9 bulan kemudian menguasai seluruh wilayah yang nantinya disebut Negara Kesatuan Republik Indonesia.

Pergerakan pasukan Jepang sangat sistematis, Hindia Belanda sebagai sasaran dianeksasi dengan kekuatan militer darat, laut maupun udara nyaris tidak mendapat perlawanan dari tentara kolonial Belanda. Rupanya pemerintah Hindia Belanda sejak tahun 1800 terlalu percaya diri terhadap kekuatan militernya tanpa menggalang kekuatan dengan potensi masyarakat jajahan kecuali hanya sebagian kecil saja, sehingga ketika terjadi serangan sporadis pemerintah Hindia Belanda hanya mampu menyingkir dari Batavia dan berakhir di Bandung.

Giliran Jepang yang menjajah. Hampir tidak ada bedanya dengan pemerintah Hindia Belanda. Sama-sama menjajah dengan cara masing-masing, tetapi penguasa militer Jepang mencoba menggunakan kekuatan lokal dari rakyat pribumi untuk membantu pertahanan Jepang. Pasukan cadangan perang buatan militer Jepang yang terdiri dari pemudapemuda pribumi dengan nama Keibodan, Seinedan, Heiho, Peta, Gakkutotai, Jibakutai, Fujinkai, Kempei-ho dan sebagainya, nyaris tidak berfungsi ketika pergerakan pasukan Sekutu menyerang mereka. Mengapa demikian? Bagaimanapun juga sebagai penjajah tentu Jepang tidak serta merta percaya seratus persen kepada pasukan cadangannya yang berasal dari orang pribumi, pasukan ini tak lebih dari kekuatan tambahan menyambut serangan balasan dari Sekutu, sehingga penggunaan sarana militer tidak sepenuhnya diberikan. Selama pelatihan dilakukan senjata yang digunakan adalah mokuju yaitu simulasi senjata dari bahan kayu Jati dan takeyari atau bambu runcing (Asmadi, 1985: 31). Bahkan ketika senjata yang sebenarnya telah diberikan, baik dengan cara penyerahan baik-baik maupun dirampas ternyata tidak memakan waktu yang lama untuk menariknya kembali. Di sinilah terjadi konfrontasi antara pasukan militer Jepang dengan pasukan Republik Indonesia. Konfrontasi lainnya terjadi setelah terbentuknya pemerintahan Republik Indonesia di mana sikap pemerintah sangat hati-hati kepada pemerintah militer Jepang.

Satu keuntungan yang diperoleh Indonesia bahwa pasukan cadangan perang Jepang dari rakyat pribumi ini justru menjadi kekuatan militer sebuah negara baru di saat status pemerintahan militer Jepang demisioner sedangkan pemerintah Hindia Belanda telah tidak berfungsi ketika Jepang menguasai Hindia Belanda. Suasana stagnan tersebut dimanfaatkan oleh rakyat pribumi untuk mendirikan sebuah negara yang diberi nama Republik Indonesia. Sejak itu peta kekuatan penjajahan di Indonesia menjadi tidak jelas dan telah terbentuk sebuah negara yang memiliki perangkat pemerintahan serta 
pasukan perang di tanah air sendiri. Pasukan perang yang tadinya terdiri dari pasukan cadangan militer Jepang harus berhadapan dengan pasukan induknya demikian pula berhadapan dengan pasukan Sekutu dan terakhir berhadapan dengan militer Belanda.

Menulis sejarah perjuangan antara tahun 1945 sampai 1950 bukanlah hal baru dan telah banyak literatur yang dihasilkan dengan berbagai analis, ditambah lagi masih bisa dijumpainya pelaku sejarah yang dapat menjadi sumber informasi primer. Namun demikian karena berbagai keterbatasan, maka tulisan tentang Perlawanan Pejuang dengan Militer Jepang Menjelang Masuknya Sekutu di Kota Bandung ini dilakukan dengan kajian kepustakaan. Adapun tujuannya disesuaikan dengan judul tulisan ini yaitu menggambarkan konfrontasi militer antara TKR dengan pasukan militer Jepang menjelang masuknya pasukan Sekutu untuk melucuti tentara Jepang. Diskripsi yang dimaksud meliputi latar belakang kehadiran militer Jepang di Bandung, posisi tentara Jepang di bawah kendali Sekutu, dan konfrontasi yang terjadi antara militer Jepang dengan pejuang.

Beberapa catatan penting tentang aksi pasukan militer Jepang sebelum dan sesudah pasukan Sekutu berada di Bandung adalah:

- Perintah Jenderal Mabuci panglima Jepang untuk Jawa Barat agar melakukan razia untuk mengambil kembali senjata-senjata yang pernah dirampas pejuang dan mengumpulkannya untuk kemudian diserahkan bersamaan dengan perlucutan nantinya.

- Pengamanan super ketat terhadap jalurjalur masuk ke Bandung seperti di Cimahi, Lembang, Sumedang, Majalaya, Baleendah, Rancaekek, Ujung Berung dijaga dengan kekuatan penuh untuk melancarkan masuknya pasukan Sekutu. Pengamanan ini ditujukan kepada pasukan TKR dan pejuang yang dikuatirkan akan mengganggu operasi perlucutan tersebut.

- Sekutu memanfaatkan tentara Jepang menjadi tameng untuk melindungi mereka dari serangan pejuang yang mengepung Hotel Preanger dan Savoy Homan.

Catatan di atas menimbulkan pertanyaan yaitu:

- Mengapa militer Jepang di Indonesia melakukan permusuhan terhadap para pejuang, padahal mereka sendiri yang membentuk pasukan cadangan?

- Sebagai sebuah kekuatan militer sebuah negara yang baru saja diproklamasikan kemerdekaannya, TKR yang anggotanya pernah dididik dan dibina secara militer oleh pasukan Jepang sebagai pasukan cadangan bahkan ditempatkan dalam berbagai posisi dan diberi pangkat militer dalam pasukan, akhirnya harus berhadapan dengan mantan komandan dan pelatih/instrukturnya itu dalam kondisi siap tempur. Mengapa kedua pasukan ini tidak dapat bekerja sama secara utuh? Misalnya militer Jepang menyerahkan secara total seluruh persenjataan mereka kepada TKR, toh pasukan Jepang nantinya akan ditawan oleh Sekutu. Mengapa militer Jepang malah mengambil sikap konfrontir kepada TKR?

- Mengapa terjadi perbedaan sikap dalam perlucutan senjata Jepang antara pejuang di Jawa Barat dengan pejuang di Jawa Timur?

Beberapa literatur menjadi pedoman dalam penulisan ini, di antaranya Bandung Awal Revolusi 1945-1946 karya John R.W. Smail yang berisi detail revolusi yang terjadi di Bandung dari peristiwa kemerdekaan RI 17 Agustus 1945 hingga peristiwa Bandung Lautan Api 24 Maret 1946.

Buku lainnya adalah Tanpa Pamrih Kupertahankan Proklamasi Kemerdekaan 17 Agustus 1945 karya Mohamad Rivai, berisi peristiwa heroik di Bandung menjelang dan hadirnya pasukan Sekutu 
untuk melucuti pasukan Jepang. Sebagian dari tulisan Rivai berisi pengalamannya ketika peristiwa tersebut terjadi.

Buku berikutnya berjudul Pelajar Pejuang karya Asmadi, berisi untaian peristiwa pasca-proklamasi terutama di wilayah Jawa Timur. Buku ini menjadi rujukan karena di dalamnya terdapat informasi tentang aksi massa dalam merampas senjata tentara Jepang yang sudah menyerah kepada Sekutu. Aksi massa ini yang akan menjadi pembanding antara kondisi di Jawa Timur dengan Jawa Barat pada situasi yang sama yaitu perlawanan terhadap tentara Jepang.

Agar berimbang, maka pembahasan tentang pengaruh dan dampak pendudukan Jepang di Indonesia dirujuk dari buku $D i$ Bawah Matahari Terbit. Sejarah Pendudukan Jepang di Indonesia 19411946 karya Nino Oktorino. Keempat buku tersebut berisi rangkaian peristiwa yang detail baik tentang peristiwa, peranan orang, dan wilayah peristiwa. Adapun tulisan ini menggabungkan beberapa rujukan yang diperoleh dari sumbersumber tertulis dan dirangkai menjadi diskripsi satu babak sejarah revolusi kemerdekaan Republik Indonesia ketika peristiwa perlucutan senjata Jepang.

\section{B. METODE PENELITIAN}

Teknik pengumpulan data yang digunakan dalam tulisan ini adalah kepustakaan yang diolah sesuai dengan metode penelitian dan penulisan sejarah dimulai dari heuristik, kritik sumber baik ekstern maupun intern, hingga menjadi suatu historiografi (Gottschalk, 1986: 34). Selain proses tersebut juga terdapat analisis dan interpretasi (Kuntowijoyo, 2013: 81), sehingga penyajian tulisan ini bersifat diskriptif analisis (Helius Sjamsuddin, 2007:238) dan historiografi yang dihasilkan termasuk dalam kategori sejarah militer, (Kuntowijoyo, 2013:106).

\section{HASIL DAN BAHASAN \\ 1. Pemerintah Hindia Belanda Mengungsi}

Berita pergerakan pasukan militer Jepang di daratan Tiongkok terus mendapat pantauan negara-negara Eropa dan Amerika, terutama setelah terjadi penggabungan dengan Jerman dan Italia pada September 1940 yang disebut Pakta Poros Berlin-Roma-Tokyo yang masingmasing ingin meluaskan pengaruh mereka. Jerman dan Italia kemudian menyetujui Kawasan Asia-Pasifik berada di bawah pengaruh Jepang. Pada tanggal 19 September 1940 Jepang menegaskan rencana "Kemakmuran Bersama Asia Timur Raya" yang meliputi wilayah inti Jepang, Cina, dan Manchuria serta wilayah luas di India, Asia Tenggara, Pasifik, Australia, hingga Selandia Baru (Oktorino, 2016:17-18). Semangat invasi Jepang telah semakin menggebu sejak 1933 dilatarbelakangi slogan "Asia untuk Asia" kemudian diubah menjadi "Jepang untuk Asia" oleh kalangan militer di Jepang dipimpin oleh Konoye Fumimaru, Hirota Koki, Laksamana Saetsugu Nobusama, dan Jenderal Matsui Iani (Oktorino, 2016: 28).

Kerajaan Belanda yang menguasai wilayah di Asia Tenggara menjadi waspada terhadap keinginan Jepang tersebut. Runtuhnya negeri Belanda oleh Jerman semakin mengkhawatirkan pemerintah Hindia Belanda. Segera Jepang menyeru kepada pemerintah Hindia Belanda agar menyerahkan wilayah jajahannya tanpa perlu peperangan. Jepang sebenarnya telah mengekspansi Hindia Belanda secara ekonomi. Tahun 1920 toko-toko Jepang menjamur di Hindia Belanda memperdagangkan barang-barang produksi langsung dari Jepang. Barangbarang seperti tekstil, perabot rumah tangga, sepeda, bir, semen, dan lain-lain dijual bebas dan langsung menguasai pasar Hindia. Bank-bank, firma-firma, perusahaan pelayaran turut mempertegas kekuasaan Jepang secara ekonomi tersebut. Akibatnya pada 1933 pemerintah Hindia Belanda sebagai penguasa memberlakukan 
pengetatan yang bertujuan membendung dominasi ekonomi Jepang tersebut serta melindungi industri tekstil dan perusahaanperusahaan dagangannya (Oktorino, 2016: 19-20). Otomatis sikap pemerintah Hindia Belanda ini menciptakan ketegangan dengan Jepang. Pada kondisi ini Jepang tidak mengendurkan semangat untuk menguasai Hindia Belanda, karena di awal Januari 1941 delegasi Jepang dipimpin Yishizawa Kenkici melakukan perundingan dengan van Mook yang berisi tuntutan Jepang agar diberi keleluasaan mengekplorasi alam Hindia Belanda mulai dari kebebasan dalam pertambangan, penangkapan ikan sampai kepada perizinan terhadap masuknya imigran Jepang secara besar-besaran. Ini ditolak mentah-mentah oleh van Mook mewakili pemerintah Hindia Belanda. Sikap ini mendorong Jepang melakukan jalan terakhir yaitu perang.

Ketika akhirnya Amerika mengembargo Jepang pada Juli 1941, Inggris dan Hindia Belanda mengikutinya. Hindia Belanda malah melakukan langkah yang mengakibatkan terhentinya pembayaran terhadap perdagangan Jepang. Akibatnya beberapa kapal tanker Jepang tidak mendapat pasokan minyak dan tertahan di pelabuhan di Kalimantan dan Sumatera (Oktorino, 2016: 51). Hal ini semakin membuat geram pemerintah Jepang dan ingin segera melaksanakan perang semesta tersebut.

Pada 6 September 1941 terjadi pertemuan penting yang menentukan arah kebijakan agresi militer Jepang di wilayah Hindia Belanda. Di hadapan Kaisar Hirohito petinggi militer Jepang memaparkan kondisi terkini yang sangat tidak menguntungkan Jepang seperti yang disampaikan oleh Laksamana Nagamo Osami Kepal Staf Angkatan Laut Jepang, akhirnya dicapai keputusan untuk melaksanakan perang. Keputusan tersebut berbunyi:

"Sehubungan dengan keinginan untuk mempertahankan diri dan demi kelangsungan hidupnya,
Kekaisaran memutuskan untuk menantang suatu peperangan dengan Amerika Serikat, Inggris, dan Belanda, dan akan berusaha menyelesaikan persiapan-persiapan militer pada akhir Oktober" (Oktorino, 2016: 52).

Pernyataan sikap tersebut menjadi sinyal bahwa Japang akan memasuki Perang Dunia II dengan sasaran Amerika Serikat, Inggris, dan Belanda. Sasaran untuk Belanda difokuskan pada wilayah Hindia Belanda di mana dalam jangka panjang jika berhasil menguasainya, maka Jepang akan mendapatkan sumber kekayaan alam yang melimpah dan akan memakmurkan Jepang seperti makmurnya negara Kerajaan Belanda. Penentuan persiapan pasukan perang Jepang hanya satu bulan kurang, tetapi persiapan invasi itu telah berlangsung lama sekali. Bulan November 1941 menjadi bulan persiapan yang sangat menentukan, laporan-laporan intelijen terus masuk baik kepada pihak Jepang maupun Amerika Serikat. Pada bulan ini pula armada Jepang berlayar menuju Hawai dipimpin Laksaman Madya Nagumo. Pada 7 Desember 1941 Laksamana Nagumo melancarkan serangan ke Pearl Harbour, bersamaan dengan itu berita pengeboman Jepang terhadap Siam, Filipina, Singapura, dan Malaya sudah diterima Gubernur Jenderal Tjarda van Starkenborgh, praktis Hindia Belanda menunggu giliran berikutnya.

Sejak Desember 1941, pasukan Jepang terus merangsek kedudukan Hindia Belanda. Jepang menerapkan strategi khusus untuk menyerang Hindia Belanda yaitu penyerangan di wilayah Timur terhadap Maluku dan Timor untuk menghambat laju pasukan Australia, di wilayah Tengah menguasai Kalimantan dan Sulawesi, di wilayah Barat penguasaan terhadap Sumatera segera dilakukan setelah menaklukkan Singapura, ini disebut Strategi Tiga Cabang (Oktorino, 2016: 84). Strategi ini ini dimaksudkan untuk menjadikan ketiga wilayah tersebut sebagai pusat kekuatan untuk menyerbu 
Jawa. Akhirnya memasuki tahun 1942 satu per satu wilayah Hindia Belanda dikuasai.

Tentara Jepang mendarat di Rembang, Eretan (Indramayu), dan Banten pada 1 Maret 1942. Sistem pertahanan Belanda yang kurang kuat memberikan perlawanan tidak berarti sehingga laju pasukan Jepang nyaris tidak terbendung. Pasukan penahan serangan Hindia Belanda yang terdiri dari pasukan KNIL dan tentara Belanda lainnya dibantu tentara Australia dan Inggris. Menariknya tentara Belanda yang tidak mampu membendung serangan Jepang tersebut akhirnya membuang senjata, mengganti seragam dengan pakaian penduduk setempat, dan pulang ke rumah masing-masing (Asmadi, 1985:16). Pemerintah Hindia Belanda di Batavia menyadari bahwa mempertahankan Hindia Belanda sudah tidak mungkin lagi, maka segera politik bumi hangus terhadap sarana dan prasarana perhubungan seperti jalan, jembatan, rel kereta api, sarana komunikasi diterapkan, kondisi ini digambarkan sebagai götterdammerung atau kiamat (Onghokham. 1989: 273) bahkan sang Gubernur Jenderal mendahului meninggalkan Batavia menuju Bandung.

Bandung menjadi tujuan pelarian petinggi Hindia Belanda dan akibat tindakan itu maka Bandung pun menjadi sasaran serangan utama militer Jepang. Disebut serangan utama karena Gubernur Jenderal Hindia Belanda, wali kota Batavia, panglima perang, dan pejabat Hindia Belanda lainnya memilih Bandung sebagai tempat pelarian, sedangkan bagi militer Jepang mendapatkan pengakuan menyerah dari petinggi Hindia Belanda adalah tujuan akhir untuk menguasai bekas jajahan tersebut. Oleh karena itu judul sub ini penulis anggap relevan sebagai latar belakang masuknya militer Jepang ke Bandung. Sekalipun fakta sejarah menyebutkan bahwa setiap daerah jajahan militer Jepang diperoleh dengan cara konfrontasi, sehingga sekalipun petinggi Hindia Belanda tidak mengungsi ke
Bandung, tetap Bandung akan dikuasai militer Jepang. Dipilihnya Bandung sebagai tempat pelarian adalah karena Bandung memang telah dipersiapkan jauh sebelum Jepang menyerang Hindia Belanda sebagai pengganti Batavia. Bandung secara geografis, topografis, geomorfologis, iklim dan lingkungannya sangat strategis menjadi ibu kota Hindia Belanda menggantikan Batavia. Posisi Bandung yang berada di cekungan dikelilingi pegunungan juga sangat mendukung menjadi penahan alami terhadap serangan musuh dari luar ${ }^{1}$. Bandung dibangun berdasarkan surat Gubernur Jenderal Hindia Belanda H.W. Daendels tertanggal 25 Mei 1810 yang menghendaki agar ibu kota Kabupaten Bandung terletak tidak jauh dari Jalan Raya Pos. Perintah tersebut kemudian diwujudkan oleh Bupati Bandung R.A Wiranatakusumah II dan secara resmi memfungsikannya sebagai ibu kota Kabupaten Bandung pada 25 September 1810 (Hardjasaputra, 119-123).

Ketika Militer Jepang akan menguasai Batavia pada 5 Maret 1942, wali kota Batavia Ir. E.A. Voorneman dan Residen Mr. C.W.A. Abbenhuis mengeluarkan pengumuman resmi agar seluruh penduduk Batavia mengurangi aktivitas dan bersikap tidak bermusuhan terhadap pasukan Jepang, dalam pengumuman itu juga disebutkan bahwa dukungan logistik mencukupi untuk seluruh warga kota (Wanhar, 2014:111). Namun demikian gencarnya serangan Jepang menyebabkan beberapa orang Belanda terutama pejabat-pejabat pemerintahan dan orang penting lainnya segera melarikan diri ke Bandung tanpa membawa keluarga mereka (Onghokham. 1989: 223-224).

Selain itu Gubernur Jenderal Tjarda van Starkenborgh telah mengungsi duluan

\footnotetext{
1 http://geohistori.blogspot.co.id/ 2010/12/bandung-sebagai-ibukotahindia.html, diakses 2 Maret 2016: 10.25 WIB.
} 
kemudian menyusul pejabat-pejabat lainnya seperti Jenderal Ter Poorten Wakil Gubernur Jenderal yang nantinya menjadi Panglima Perang Hindia Belanda. Pengumuman wali kota Batavia yang mencoba menenangkan warganya dengan menyebut ketersediaan logistik mencukupi dan tidak perlu meninggalkan Batavia, hanya berlaku bagi masyarakat lainnya, ini dilakukan untuk mencegah agar Bandung tidak menjadi penuh sesak oleh para pengungsi (Onghokham.1989:224 254). Namun aliran deras pengungsi ke Bandung akhirnya tidak terbendung, Bandung menjadi sesak karena beragam orang dengan profesi berbeda telah tiba, bahkan pasukan KNIL juga turut mundur ke Bandung, sehingga sikap pantang menyerah yang tadinya diperlihatkan petinggi Hindia Belanda ${ }^{2}$ melunak terutama setelah ada tekanan dan ancaman dari pimpinan tertinggi militer Jepang.

Kota Bandung telah dipersiapkan sebagai pusat kegiatan pemerintahan Hindia Belanda jika sewaktu-waktu Batavia dikuasai musuh. Oleh karena itu Bandung menjadi kota penentu takluk tidaknya pemerintah Hindia Belanda kepada Militer Jepang. Dengan demikian Bandung dapat disebut sebagai pusat pemerintahan Hindia Belanda pascaruntuhnya Batavia. Ternyata, setelah menguasai Batavia, pasukan Jepang terus merangsek mengejar para petinggi Hindia Belanda. Tujuan mereka adalah menyerah

2 Menjelang akhir bulan Februari 1942 Jenderal Ter Poorten menggunakan kalimat "liever staande sterven dan knielende leven" (lebih baik mati berdiri daripada hidup bertekuk lutut) dan menjadi slogan di siaran radio stasiun NIROM di Bandung (Onghokham, 1989:254-257). Kalimat ini disampaikan sebagai penegas sikapnya yang akan mempertahankan Hindia Belanda dan ini sesuai dengan perintah dari kabinet Belanda di London untuk tidak menyerah dalam keadaan apa pun, kemudian berubah dengan menyerah tanpa syarat pada tanggal 8 Maret 1942. Penyerahan ini diumumkan melalui radio NIROM (Onghokham, 1989:263). kalahnya pemerintah Hindia Belanda kepada Militer Jepang. Sepanjang pemerintah Hindia Belanda belum menyerah, maka pasukan Jepang terus mengejar.

Patut diperhatikan selama aneksasi Jepang di Hindia Belanda satu-satunya wilayah yang tidak pernah diduduki oleh Militer Jepang adalah Merauke (Wanhar, 2014:112). Kenapa pemerintah Hindia Belanda tidak membangun pusat pemerintahan di sana? Malah memilih Bandung yang jaraknya relatif dekat dengan Batavia dan dapat dengan mudah dijangkau dari segala arah.

\section{Jepang Mengejar ke Bandung}

Pergerakan pasukan Jepang yang demikian cepat tidak serta merta terjadi. Pemerintah Jepang telah mempelajari seluruh kondisi Hindia Belanda sampai pada progresivitas pergerakan rakyat pribumi. Orang-orang Jepang telah ada di Hindia Belanda sejak 1873 yaitu di Aceh, kemudian 1883 di Jawa, dan seterusnya (Astuti, 2008: 82-87). Keberadaan orang Jepang ini sebagai bagian dari Restorasi Meiji yaitu menjalin jaringan internasional (Astuti, 2008: 25). Mereka berprofesi sebagai pedagang dan pemilik toko jika bermukim di perkotaan atau menjadi pemilik lahan perkebunan di pedesaan. Beberapa di antara mereka menjadi aparat sipil setelah pemerintahan militer didirikan di Indonesia seperti Sato Shigeru pemilik Toko Sato di Bandung menjadi pegawai bidang kesehatan di Semarang (Astuti, 2008:132). Ini menguatkan dugaan bahwa mereka adalah mata-mata pemerintah Jepang di Hindia Belanda (Astuti, 2008: 132). Maka bisa dimengerti bahwa Jepang memahami keinginan bangsa pribumi, dan ini dimanfaatkan ketika mereka menganeksasi pemerintah Hindia Belanda dan melakukan pendekatan dengan rakyat Indonesia dengan propaganda Gerakan 3A dan pembentukan Poetra. Akibatnya tentara Hindia Belanda tidak mendapat pertolongan sama sekali dari rakyat pribumi ketika Jepang menyerang mereka. 
Setelah menguasai Batavia, pasukan Jepang segera bergerak ke Bandung. Untuk masuk ke Bandung 5000 pasukan Jepang yang dipimpin oleh Kolonel Toshinori Shoji ${ }^{3}$ mendarat di Eretan Wetan (sekarang dalam wilayah Kabupaten Indramayu) kemudian berhasil menguasai Subang pada 1 Maret 1942 (Poesponegoro, 1993: 3). Setelah itu mereka menguasai Lapangan Udara Kalijati sesudah menaklukkan pasukan KNIL di sana. Jarak dari Kalijati ke Bandung hanya $40 \mathrm{~km}$. Setelah Subang, Kalijati, menyusul Lembang. Dengan dikuasainya Lembang maka pintu utara menuju Bandung sudah terbuka.

Gerak cepat tentara Jepang dibawa komando Panglima Tentara ke-16 Jenderal Hitoshi Imamura membuat pemimpin Hindia Belanda yang saat itu berkedudukan di Bandung tidak dapat berbuat banyak, maka pada tanggal 8 Maret 1942 dilakukanlah Perjanjian Kalijati di wilayah Kabupaten Subang antara Jenderal Ter Poorten ${ }^{4}$ selaku Panglima Tertinggi Angkatan Bersenjata Hindia Belanda dengan Jenderal Hitoshi Imamura sebagai pimpinan pasukan Jepang. Perjanjian ini sebagai tanda menyerah tanpa syaratnya pemerintah Hindia Belanda kepada militer Jepang ${ }^{5}$.

3 Nino Oktorino menulis nama Kolonel Shoji Toshishige (Oktorino, 2016: 185).

4 Penyerahan pimpinan perang kepada Jenderal Ter Poorten dari Gubernur Jenderal Hindia Belanda Tjarda Van Stackenborg Stackhouwer berdasarkan pada telegram peemerintah Kerajaan Belanda yang sedang mengungsi di London pada tanggal 5 Maret 1942 (Onghokham, 1989: 262). Sejak itu urusan perang diserahkan kepada Jenderal Terporten sedangkan Gubernur Jenderal hanya melakukan kegiatan pemerintahan sipil saja. Oleh sebab itu Gubernur Jenderal tidak dianggap lagi oleh Imamura sehingga keputusan menyerahnya Hindia Belanda ada ditangan Jenderal Terporten (Onghokham, 1989: 264-266).

5 Menyerahnya Panglima Tertinggi Hindia Belanda Jenderal Ter Porten dianggap
Sejak itu militer Jepang memulai pendudukannya dengan mendirikan pemerintahan militer sedangkan pemerintah Hindia Belanda sudah tidak ada.

Keberhasian yang cepat atas perang yang gencar dilakukan Kerajaan Jepang, ternyata tidak dibarengi dengan pasukan pengelola administrasi pemerintahan. Onghokam menyebutkan bahwa dalam situasi darurat tersebut ada indikasi Imamura akan tetap menggunakan jasa Binnenland Bestuur untuk menjalankan roda pemerintahan sipil, dan ini mendapat sinyal persetujuan dari penguasa Hindia Belanda (Onghokham, 1989: 271). Apalagi Gubernur Jenderal memang merasa tidak pernah takluk kepada militer Jepang. Ini semakin meningkatkan kepercayaan diri penguasa Hindia Belanda bahwa urusan rakyat Hindia Belanda hanya bisa ditangani oleh pemerintah Hindia Belanda. Sikap ini kemudian padam dengan sendirinya setelah pihak Jepang menyodorkan surat bersedia "sumpah setia" kepada tentara Jepang (Onghokham, 1989: 269). Tentu saja harga diri Belanda menjadi tersinggung, sejak memulai penjajahan mereka telah mendudukkan kasta-kasta di Hindia Belanda di mana orang-orang Belanda dan Eropa berada di kasta tertinggi menyusul bangsa-bangsa lainnya dan bangsa pribumi adalah bangsa yang paling rendah. Sekarang tiba-tiba mereka diharuskan bersumpah setia kepada Jepang yang baru saja menaklukkan mereka, maka

bukan mewakili pemerintah sipil Hindia Belanda. Sikap Ter Porten menurut Gubernur Jenderal van Starkenborgh hanya sebagai tanda menyerahnya pasukan KNIL saja, sedangkan pemerintahan sipil Hindia Belanda masih tetap berjalan. Dengan demikian dia tidak melanggar perintah London untuk tidak boleh menyerah kepada Jepang (Oktorino, 2016: 191). Sementara bagi Imamura menyerahnya Ter Porten sudah cukup sebagai tanda persetujuan pemerintah Hindia Belanda. 
yang menjadi pilihannya adalah tetap menjadi tawanan.

Pemerintah militer Jepang kemudian membentuk pemerintahan pendudukan dengan menempatkan Indonesia di bawah komando Tentara Wilayah Selatan yang berkedudukan di Dalat, Vietnam dipimpin oleh Marsekal Terauchi Hisaichi. Indonesia kemudian dibagi tiga wilayah yaitu: Samu Shudan untuk Jawa dan Madura markasnya di Jakarta (Batavia tidak dipergunakan lagi), Tomi Shudan untuk Sumatera markasnya di Bukittinggi (sebelumnya di Singapura), dan Dai Ni Nankenkantai untuk Kalimantan, dan bagian timur bermarkas di Makassar (Oktorino, 2016: 203-204). Dengan ketiga pusat pendudukan inilah bekas Hindia Belanda diperintah secara militer hingga Agustus 1945.

Demikianlah secepat gerakan invasi militer Jepang tersebut, namun hanya memiliki masa kekuasaan yang pendek. Awal tahun 1943 gerakan militer Sekutu telah mempersulit posisi Jepang di negeri jajahannya dan kekalahan demi kekalahan harus mereka terima. Puncaknya setelah Hiroshima dan Nagasaki dibom atom oleh Amerika Serikat masing-masing pada 6 Agustus 1945 dan 9 Agustus 1945. Dua peristiwa ini yang membuat Kaisar Jepang harus menyerah kepada Sekutu pada 15 Agustus 1945.

Berita takluknya negeri Jepang setelah Kaisar Hirohito menyatakan menyerah kepada Sekutu segera menyebar ke seluruh dunia terutama wilayah ekspansi pasukan militer Jepang. Aksi kamikase ketika awal penyerangan ke mancanegara berganti dengan kesedihan dan rasa putus asa. Tidak sedikit yang melakukan harakiri (bunuh diri) untuk menutupi rasa malu. Tetapi apa pun tindakan mereka, pelajaran berharga yang telah diperlihatkan pasukan Jepang adalah kepatuhan yang tinggi terhadap kaisar mereka. Bisa saja pasukan Jepang yang bersenjata lengkap dan jauh dari negeri asalnya tersebut membangkang atau memberontak mumpung di negeri jajahannya sedang berkuasa, tetapi sikap yang akhirnya dipilih adalah tunduk kepada perintah kekaisaran yaitu menyerah tak bersyarat yang ditandatangani pada 2 September 1945 di atas kapal perang Amerika Serikat Missouri.

Beberapa informasi menyebutkan bahwa di wilayah-wilayah terpencil di Asia pasukan Jepang ada yang tidak mau menyerah sampai berbulan-bulan bahkan tahunan pasca perintah menyerah tersebut. Ini bisa jadi karena mereka tidak mendapatkan informasi yang akurat dan kuatnya sikap pantang menyerah. Akan tetapi lambat laun mereka harus tunduk pada perintah kekaisaran tersebut. Sikap pantang menyerah pasukan Jepang juga diperlihatkan dimana ada beberapa bekas tentara Jepang yang kemudian menyerahkan senjatanya secara sukarela kepada pejuang, bahkan ada yang bergabung dengan pejuang menghadapi Sekutu dan Belanda (Sufian, 1987:87).

\section{Konfrontasi}

Konfrontasi mengandung arti pertentangan atau permusuhan. Konfrontasi adalah pertentangan atau permusuhan yang dilakukan secara langsung dan berhadap-hadapan (Depdiknas, 2008: 723). Konfrontasi ini terjadi karena militer Jepang yang sudah menyerah kepada Sekutu tetap tidak mau menyerahkan senjatanya kepada pejuang, sehingga beberapa aksi perampasan sempat terjadi. Di lain pihak pasukan Jepang mempertahankan persenjataan mereka karena terikat pada kehendak Sekutu yang akan memperlakukan tawanan perang sesuai Konvensi Jenewa.

Konfrontasi antara Republik Indonesia dengan pemerintah militer Jepang mencapai puncaknya terutama setelah terbentuknya susunan pemerintahan Republik Indonesia. Pemerintah bersikap hati-hati dan lebih memilih kesepakatan dengan Jepang, sementara dalam waktu bersamaan para pemuda yang dimotori oleh mantan 
pasukan cadangan militer Jepang memilih sikap untuk segera memanfaatkan keadaan lemahnya posisi Jepang dan mumpung Sekutu belum tiba dan melaksanakan tugasnya. Konfrontasi yang terjadi dijabarkan sebagai berikut:

\section{- Dengan Pemerintah Republik Indonesia}

Di Indonesia, berita menyerahnya Jepang kepada Sekutu tidak segera diterima. Terbatasnya akses komunikasi menyebabkan informasi penting itu tidak sampai kepada seluruh rakyat Indonesia. Bahkan berita menyerahnya kaisar Jepang menjadi berita yang sangat rahasia. Pemerintah pendudukan masih tetap melaksanakan tugas-tugasnya termasuk janji memerdekakan Indonesia.

Konstelasi politik terutama pada bulan Agustus 1945 di Indonesia semakin memanas. Informasi tentang pemboman Sekutu di negeri Jepang dan menyerahnya Kaisar Hirohito sempat didengar oleh beberapa pemuda dari siaran radio gelap. Informasi ini kemudian diteruskan kepada tokoh-tokoh yang sedang merumuskan kemerdekaan Indonesia sesuai janji Jepang, tetapi mereka tidak mempercayai informasi tersebut. Konsentrasi para tokoh tersebut adalah tanggal 24 Agustus 1945 Indonesia akan dimerdekakan oleh Jepang. Berbagai persiapan dilakukan terutama setelah Soekarno dan Hatta resmi diangkat sebagai ketua dan wakil ketua PPKI oleh Marsekal Terauchi Hisaichi, panglima Tentara Jepang Wilayah Selatan berkedudukan di Saigon. Sikap kedua negarawan yang tetap kukuh agar prosedur kemerdekaan tersebut tetap melalui PPKI mendapat perlawanan dari kaum muda yang lebih menghendaki agar pengumuman kemerdekaan tersebut segera dilaksanakan karena Jepang tidak lagi berkuasa atas Indonesia setelah berita menyerahnya kekaisaran Jepang kepada Sekutu. Akhirnya setelah melalui perdebatan yang cukup alot, disertai dengan drama penculikan terhadap Soekarno dan Hatta, maka atas nama bangsa Indonesia Soekarno memproklamasikan kemerdekaan Indonesia pada tanggal 17 Agustus 1945, tujuh hari sebelum janji kemerdekaan dari Jepang akan dilaksanakan.

Setelah proklamasi kemerdekaan dan susunan pemerintahan terbentuk, maka mulailah diplomasi atas nama bangsa Indonesia kepada penguasa militer Jepang yang masih bertahan sebagai tentara pendudukan. Diplomasi yang lebih tepatnya disebut negosiasi itu terjadi karena sikap Jepang masih memosisikan diri sebagai penguasa dengan modal masih memegang senjata. Walaupun janji kemerdekaan tidak pernah dipenuhinya. Pemerintah Indonesia terutama golongan tua yang dipelopori Soekarno dan Hatta sangat berhati-hati dalam negosiasi tersebut. Dalam pelantikan KNIP tanggal 29 Agustus 1945, Soekarno menyebutkan bahwa sebagai pemegang status quo otoritas telah berada di tangan Indonesia misalnya untuk posisi jabatan-jabatan penting (menteri Republik sekaligus pejabat tinggi dalam hirarki pemerintahan militer Jepang), sedangkan posisi militer Jepang adalah mempertahankan keamanan dan keteraturan sosial (ketertiban), sehingga alur diplomasi adalah gentlement's agreements (Smail, 2011:35). Gentlement's agreements adalah kesepakatan tanpa saling merusak untuk mencapai suau tujuan, dan tujuan pemerintah Republik Indonesia adalah kelak menjadi otoritas penuh untuk Indonesia. Satu-satunya kesepakatan yang masih diperhitungkan sebagai hal yang rawan adalah membentuk pasukan militer sebagai satu bagian penting terhadap berdirinya suatu negara. Karena kondisi ini terdapat posisi unik di bawah Menteri Keamanan yang dijabat oleh Otto Iskandar Dinata yaitu, jika menteri lainnya memiliki staf orang Indonesia, Otto memiliki pasukan militer Jepang. Posisi Otto ini hanya pelengkap kabinet saja karena kendali penuh terhadap militer Jepang tetap ada pada penguasa Jepang. Hal ini 
berangsung hingga masuknya bulan Oktober 1945 (Smail, 2011: 37).

Bagi Indonesia, pembentukan unit militer adalah hal yang sangat penting di masa itu tetapi menyampaikannya kepada penguasa militer Jepang menjadi suatu permasalahan tersendiri. Tentu dapat dimengerti posisi Jepang saat itu adalah taklukan Sekutu tetapi mereka masih memegang senjata sampai nanti akan dilucuti. Paling tidak ada dua alasan Jepang untuk tidak menyetujui pembentukan unit militer Republik apabila diajukan dalam kesepakatan tersebut: Pertama, kekuatan pasukan Peta yang berjumlah 35.000 orang (Smail, 2011: 36) dengan kemampuan bertempur yang memadai (sekalipun belum pernah diturunkan dalam perang secara langsung), bisa jadi bumerang bagi Jepang. Kekuatan tersebut meliputi penguasaan strategi dan persenjataan. Oleh sebab itu Jepang segera membubarkan Peta dan Heiho serta melucuti persenjataan yang ada pada mereka, karena kekuatan ini akan menyulitkan Jepang nantinya. Apalagi beberapa peristiwa yang dikategorikan militer Jepang sebagai pemberontakan sempat terjadi seperti di Cot Plieng Lhokseumawe (1942) dan Meureudu Aceh (November 1944) ${ }^{6}$, Blitar (14 Februari 1945) (Arifin, 1996: 168-172), Karangampel (1943) dan Cilacap (21 April $1945)^{7}$, Singaparna (1944) dan Cileunca Pagalengan (4 Mei 1945) (Suryanegara, 1996: 165-169, 237), dan Rengasdengklok (16 Agustus 1945) (Notosusanto, 1990: 81). Kedua, ketentuan Sekutu adalah militer Jepang menyerahkan diri bersama peralatan militernya sehingga jika Jepang menyerahkan persenjataan mereka kepada Republik Indonesia akan memberi dampak negatif bagi Sekutu karena Sekutu akan

6 http://sejarahbudayanusantara.weebly.com /jepang.html. Diakses 1 April 2017, 09.05 wib.

7 http://astiannew.blogspot.co.id/2015/06/ pemberontakan-peta-di-cilacap.html. Diakses 1 April 2017, pukul 08:35 wib. bekerja keras untuk mengumpulkan atau melucuti senjata-senjata tersebut nantinya. Jika ini terjadi, maka proses pemulangan sisa tentara Jepang akan memakan waktu yang lama dan bagi militer Jepang jika nanti terjadi peperangan antara Sekutu dengan Republik maka Jepang yang berada di tengah-tengah bisa jadi sebagai korban.

\section{- Dengan Pejuang}

Pasukan cadangan perang Jepang di Indonesia dibentuk untuk membantu militer Jepang dalam menghadapi serangan balasan pasukan Sekutu dalam rangka pertahanan semesta, sebagai antisipasi seranngan balik Sekutu. Anggota pasukan ini direkrut dari pemuda-pemuda Indonesia dari berbagai kalangan dan latar belakang. Mereka kemudian dididik dengan disiplin militer termasuk cara berperang dan pengenalan struktur dalam kemiliteran. Pasca-proklamasi kemerdekaan, pasukan cadangan ini tidak lagi berada di bawah kepemimpinan militer Jepang. Mereka para mantan pasukan cadangan yang berasal dari Peta, Heiho, dan organisasi semi militer lainnya ada yang bergabung dalam BKR sisanya bergabung dalam laskar-laskar atau milisi-milisi yang telah bermunculan.

Sebelum menjadi Tentara Keamanan Rakyat (TKR), telah dibentuk BKR (Badan Keamanan Rakyat) pada 22 Agustus 1945 oleh PPKI sebagai bagian dari Badan Penolong Keluarga Perang (BPKKP). BKR dibentuk sebagai organisasi nonmiliter yang merupakan cikal bakal pasukan tentara kebangsaan Indonesia (Asmadi, 1985:102). Sebagai organisasi nonmiliter ternyata anggota BKR melakukan tindakan perampasan senjata terhadap anggota pasukan Jepang yang mereka temui. Akibatnya di Bandung pasukan Jepang yang tergabung dalam Dokuritsu Konsei Ryodan ke-27 dibuat tidak berdaya dan dilucuti senjatanya. Aktivitas BKR terus meluas dengan menyerbu markas kodam Jepang seperti Seibu Jawa Bo-eitai, Chubu Jawa Bo-eitai, dan Tobu Jawa Bo-eitai. Tindakan BKR 
ini memberikan hasil karena pada 5 Oktober 1945 pemerintah Indonesia di Jakarta akhirnya membentuk Tentara Keamanan Rakyat (TKR) sebagai pasukan perang Indonesia (Asmadi, 1985: 103).

Sebagai sebuah oranisasi militer resmi sebuah negara maka diangkatlah Letnan Jenderal Oerip Soemohardjo pada 14 Oktober 1945 sebagai Kepala Staf Umum TKR dan bermarkas di Yogyakarta. Tugas kepala staf ini adalah membentuk TKR di seluruh wilayah Indonesia di Jawa dan Sumatera. Akhirnya terbentuklah 10 Divisi TKR di Jawa dan 6 Divisi di Sumatera lengkap dengan wilayah masingmasing dan penentuan pimpinannya. Untuk wilayah Priangan yang meliputi: Bandung, Sumedang, Sukabumi, Tasikmalaya, Ciamis, Garut, Cimahi, dan Cianjur dibentuk Divisi III dipimpin oleh Kolonel Arudji Kartawinata dan bermarkas di Bandung. Wilayah Priangan lainnya yaitu Bogor masuk dalam Divisi II bersama Jakarta dan Cirebon dipimpin oleh Kolonel Asikin bermarkas di Linggajati (Asmadi, 1985: 107). Turut diangkat pula Mayor Nasution sebagai Kepala Staf Komandemen TKR Jawa Barat. Dalam rangka pengisian organisasi militer ini, Nasution terus melakukan safari di wilayah Jawa Barat untuk membentuk resimen-resimen TKR. Bersamaan dengan pembentukan TKR bermunculan juga organisasi-organisasi perjuangan seperti Laskar Rakyat, Hisbullah, Barisan Pemberontak, Angkatan Pemuda Indonesia (Nasution, 1990:175). Organisasi massa ini tidak dapat diatur berdasarkan aturan komandemen, sehingga segala tindakannya sekehendak mereka. Inilah yang melakukan penyerangan dan perlucutan senjata terhadap pos-pos Jepang. Akibatnya mereka melakukan kekacauan yang mengancam eksistensi Republik Indonesia. Imbasnya kepada TKR yang disamakan dengan laskar atau milisi sebagai pemberontak dan perampok.

Sejak dibentuknya TKR aktivitas penyerangan terhadap posisi tentara Jepang menjadi kancah peperangan dan dilakukan oleh sebuah organisasi militer Indonesia. Permasalahan yang muncul setelah terbentuknya TKR adalah anggota pasukan kekurangan persenjataan terutama yang ada di Jawa Barat. Senjata-senjata yang ada adalah hasil rampasan itu pun tidak semua pos militer dan markas militer Jepang berhasil di lucuti. Persoalan pun bertambah karena sesuai perintah Sekutu, militer Jepang harus menyerahkan diri beserta persenjataan yang lengkap (Nasution, 1990:190). Perintah Sekutu ini disampaikan sebagai syarat penarikan pasukan Jepang dari Indonesia bersama persenjataan lengkap mereka, sesuai dengan pasal 18 Konvensi Jenewa II tahun 1929 yang tertulis:

"All effects and articles of personal use, except arms, horses, military equipment and military documents, shall remain in the possession of prisoners of war, likewise their metal helmets and gas masks and like articles issued for personal protection. Effects and articles used for their clothing or feeding shall likewise remain in their possession, even if such effects and articles belong to their regulation military equipment. $^{8}$

Selain itu pada tanggal 15 Agustus 1945, Markas Besar Umum Kerajaan Jepang mengeluarkan perintah yang pada pokoknya agar seluruh pasukan Jepang harus menghentikan perang melawan Sekutu serta meletakkan senjata. Turut ditetapkan dalam perintah tersebut adalah agar para panglima Jepang di wilayah jajahan harus melucuti senjata seluruh pasukan di bawah kekuasaan masingmasing dan peralatan militer harus diserahkan lengkap dan utuh kepada Panglima Sekutu (Asmadi,1985: 52).

Meski pengumuman tersebut dikeluarkan pada 15 Agustus 1945, namun baru pada 11 Oktober 1945 Jenderal Mabuci Panglima Jepang untuk wilayah

8 http://www.un-documents.net/gc-3.htm. Diakses 11 Januari 2017, pukul 11:35 wib. 
Jawa Barat memerintahkan seluruh senjata yang telah direbut oleh pejuang agar segera dikembalikan, oleh karena itu seluruh pasukan Jepang diperintahkan melakukan segala cara untuk mengumpulkan kembali senjata-senjata tersebut. Senjata-senjata dan peralatan militer lainnya nantinya akan diserahkan bersamaan dengan perlucutan oleh Sekutu.

Pasukan Jepang melakukan razia besar-besaran di Kota Bandung, tujuan razia ini adalah untuk merebut kembali senjata yang telah dilucuti pejuang dan sebagai tindakan pengamanan menjelang kedatangan Sekutu pada tanggal 12 Oktober 1945. Dampak razia ini pasukan pejuang tidak bisa berbuat banyak kecuali menghindar untuk sementara karena melakukan tindakan balasan dengan kondisi persenjataan yang kurang akan berkesan seperti bunuh diri (Rivai, 1984:73). Pasukan Jepang kemudian membuat barikade ketat di semua pintu masuk ke Kota Bandung seperti di Lembang, Sumedang, Majalaya, Baleendah, dan Ujungberung (Rivai, 1984:73). Peristiwa tersebut terjadi ketika Sekutu akan masuk ke Bandung dan sejak itu konfrontasi antara tentara Jepang dengan rakyat Indonesia terus berjalan.

Aksi pasukan Jepang tersebut membuat TKR di Jawa Barat mengambil tindakan menahan diri, hal ini karena sebelumnya pada tanggal 8 Oktober 1945 Gubernur Jawa Barat Sutardjo Kartohadikusumo, Residen Datuk Djamin, dan Residen Ardiwinangun (ketua Komite Nasional Indonesia) telah mengumpulkan seluruh pimpinan TKR untuk diarahkan agar kedatangan Sekutu ke Bandung disambut dengan damai tanpa ada perlawanan (Asmadi,1985: 71) dan pasukan Jepang sebagai pihak yang nanti akan dilucuti oleh Sekutu tidak diserang karena telah menjadi urusan Sekutu untuk melucutinya.

Masa antara 15 Agustus sampai 11 Oktober 1945 adalah masa paling pahit bagi pemerintah militer Jepang, sebab dalam masa itu mereka diperintah untuk menyerah sebagai taklukan perang di lain pihak beberapa persenjataan yang seharusnya diserahkan nantinya telah dirampas oleh pejuang.

Sementara bagi pemerintah dan pejuang Republik kondisi ini menimbulkan dilema, karena apabila tentara Jepang diserang maka secara politis pemerintah Indonesia dianggap melakukan pelanggaran terhadap tawanan perang. Di sisi lain takluknya Jepang kepada Sekutu adalah modal besar dalam hal persenjataan. Bagi pejuang biarlah tentara Jepang dibawa oleh Sekutu tetapi senjata dan peralatan militernya diserahkan kepada pemerintah Indonesia dalam hal ini TKR untuk menjadi alat pertahanan.

Setelah Sekutu berhasil masuk ke Bandung, kembali tentara Jepang dijadikan tameng untuk menghadapi pejuang. Pengerahan pasukan Jepang ini adalah untuk mengamankan para perwira Sekutu yang bermarkas di Hotel Preanger dan Savoy Homan karena kedua hotel ini dikepung oleh pejuang. Tentara Jepang mengerahkan panser-panser untuk menghalau pejuang. Pejuang yang terdiri dari laskar dan TKR menahan diri untuk tidak berkonfrontasi dengan Jepang karena status pasukan Jepang adalah tawanan perang (Rivai, 1984: 91). Jika pasukan Jepang diserang, maka Indonesia akan mendapat kecaman dunia internasional sebagai negara yang menyerang pasukan yang tidak berdaya dan dalam pengawasan Sekutu.

Posisi pejuang di Jawa Barat khususnya di Bandung memang dilematis, sebab ketika momen penting untuk melucuti senjata pasukan Jepang yang telah takluk tidak dapat dilaksanakan karena pemerintah Indonesia dapat dengan cepat mencegah hal tersebut terjadi ${ }^{9}$. Ini

9 Salah satu alasan yang digunakan pemerintah Indonesia agar pejuang menhan diri adalah pertemuan antara Mayor Jenderal Yamamoto Kepal Staf Tentara ke16 Jepang dengan Bung Hatta. Yamamoto menjelaskan bahwa bangsa Indonesia hendaknya memperlihatkan kesan kepada 
disebabkan jarak antara Jakarta dengan Bandung yang relatif dekat demikian pula alur informasi dapat diakses dengan cepat baik melalui kurir, telepon, telegraf, kereta api dan sebagainya, sehingga seluruh informasi dan perintah dari pemerintah dapat segera sampai. Inilah yang kemudian menahan mereka untuk tidak bertindak melucuti dan menyerang tentara Jepang, sekalipun beberapa peristiwa sebelumnya sempat dilakukan pelucutan tersebut yang menyebabkan Jenderal Mabuci memerintahkan razia untuk mengumpulkan kembali senjata yang telah diambil pejuang tersebut.

Demikianlah konfrontasi pejuang di Jawa Barat khususnya di Kota Bandung terhadap militer Jepang tidak seramai dengan di Jawa Timur. Konsolidasi pasukan pejuang di Jawa Barat berlangsung terus menerus baik yang dilakukan pemerintah Provinsi Jawa Barat, Residen Bandung maupun oleh Kepala Staf Komandemen TKR Jawa Barat.

Berbeda dengan pejuang yang ada di wilayah Jawa Timur. Akibat jarak yang jauh dan sarana komunikasi yang terbatas (bumi hangus terhadap sarana komunikasi seperti telepon oleh Belanda ketika Jepang akan menguasai Jawa Timur) sehingga perintah dari pemerintah pusat terlambat bahkan tidak sampai. Oleh karena itu TKR dan laskar yang ada di Jawa Timur sempat melucuti seluruh pasukan Jepang di sana. Terhitung sejak 16 September 1945 sudah dimulai perlucutan senjata tersebut hingga 3 Oktober 1945 sehingga hampir seluruh anggota BKR sudah memiliki senjata demikian pula dengan anggota laskar

dunia sebagai bangsa yang tertib dan beraturan, bersatu padu melakukan gerakan secara teatur dengan jalan damai (mempertahankan kemerdekaan yang telah diproklamasikan). Percakapan ini terjadi karena aksi perampokan (perlucutan) yang semakin menjadi terutama di Jawa Timur (Nasution, 1990:151). Jadi pemerintah militer Jepang menganggap aksi perampasan senjata tak lebih dari aksi perampokan. lainnya (Asmadi, 1985: 89-94). Ini menjadi modal mereka ketika terjadi pertempuran di Surabaya pada 10 November 1945. Karena kurangnya informasi dari pusat, pesawat yang membawa Presiden Soekarno dan Wapres Hatta untuk menenangkan rakyat Surabaya sempat diserang dengan gencar oleh TKR Pelajar Stav IV (Asmadi, 1985: 143-145).

Menghadirkan presiden dan wakil presiden oleh Sekutu adalah langkah putus asa pasukan Sekutu dalam menghadapi sikap patriotik masyarakat Jawa Timur khususnya Surabaya. Tetapi ada yang unik yaitu bahwa Sekutu kewalahan di Surabaya dan menempuh cara tersebut, ini membuktikan bahwa Sekutu mengakui hegemoni pemimpin Republik terhadap rakyatnya dan sekaligus menjadi pengakuan terhadap kepemimpinan sebuah negara. Terbukti pasca-turunnya presiden dan wakil presiden ke Jawa Timur, kondisi keamanan berangsur membaik meski para pejuang tetap bersiaga penuh karena musuh yang sebenarnya yaitu kembalinya Belanda semakin mendekati kenyataan.

Konfrontasi dalam bentuk perang semesta terjadi nanti setelah Sekutu memperlihatkan keinginan sebenarnya yaitu menempatkan kembali Belanda sebagai penguasa atas Indonesia, yang mendapat perlawanan baik secara diplomasi maupun beragam pertempuran hingga berlangsungnya Konferensi Meja Bundar di Den Haag tanggal 29 Desember 1949.

\section{PENUTUP}

Konfrontasi di masa revolusi kemerdekaan Republik Indonesia terutama dalam babak pendudukan militer Jepang ditandai dengan merdekanya Bangsa Indonesia sebelum waktu pemberian kemerdekaan yang dijanjikan oleh militer Jepang. Pasca-proklamasi ini sekalipun susunan pemerintahan Republik telah terbentuk tetapi masih ada rangkap jabatan di mana satu sisi menjadi menteri Republik sisi lain menjadi pejabat tinggi dalam pemerintahan militer Jepang. Sistem 
pengambilan keputusan berdasarkan gentlement's agreement atau kesepekatan karena militer Jepang masih menganggap dirinya berkuasa atas Indonesia sampai penyerahan kepada Sekutu nantinya. Sikap kaum tua yang dipelopori oleh Soekarno lebih memilih negosiasi atau diplomasi dalam merebut kekuasaan militer Jepang, sedangkan sikap kaum muda menghendaki tindakan tegas karena menganggap Jepang tidak lagi berkuasa atas Republik Indonesia.

Konfrontasi juga terjadi antara milisi yang terdiri dari pemuda-pemuda yang pernah dilatih militer oleh Jepang dengan sisa pasukan militer Jepang yang sudah takluk kepada Sekutu. Perselisihan terjadi kemudian mengarah kepada kekerasan seperti pembunuhan terhadap tentara Jepang dan perampasan senjata mereka, puncaknya adalah perintah Jenderal Mabuchi agar senjata yang telah dirampas segera dikembalikan diikuti dengan tindakan razia yang brutal.

Pasukan Sekutu memanfaatkan hasil Konvensi Jenewa untuk menekan Jepang secara politis sehingga pelaksanaan perlucutan sisa tentara Jepang harus dengan perlengkapan militernya. Ini bermakna dua arah: Pertama, bagi Sekutu pengalaman diserang dengan gerak cepat oleh militer Jepang sudah merupakan trauma yang harus dihindarkan sehingga mengumpulkan segala peralatan militer Jepang adalah hal yang sangat diperlukan. Kedua, Sekutu dalam perlucutan Jepang ini tidak mau mengambil risiko mendapat serangan dari bekas tentara Jepang dan cadangannya yang terdiri dari pejuang Republik jika peralatan militer tersebut diserahkan oleh Jepang kepada pemerintah Indonesia.

Bagi Indonesia, keberadaan militer Jepang telah memberi banyak pelajaran di antaranya; Pertama, Pemerintahan militer Jepang mau mendidik dan melatih pemuda Indonesia menjadi anggota militer sekalipun sebagai pasukan cadangan. Akibat pelatihan ini jiwa nasionalisme yang telah tumbuh di masa pemerintahan
Hindia Belanda menjadi sikap patriotik. Kedua, dengan latihan militer ini menjadi cikal bakal terbentuknya organisasi militer dengan struktur jabatan dan kepangkatan yang jelas. Ketiga, pembelajaran yang juga diperoleh adalah pola strategis pengaturan pasukan dan gerakan militer yang patuh pada komando menjadi warisan yang utama. Keempat, menjadi tambahan wawasan berharga bagi militer Indonesia dalam menghadapi gerak dan kekuatan pasukan Belanda di kemudian hari seperti terciptanya ide perang gerilya. Dari kesemuanya, yang paling utama adalah bahwa menghadapi pasukan Belanda tidak perlu lagi secara sembunyi-sembunyi seperti masa-masa pergerakan, tetapi berani menghadapi kekuatan Belanda dengan kemampuan sendiri. Satu-satunya kelemahan pasukan Republik Indonesia adalah kurangnya senjata dan peralatan militer lainnya.

Masa pemerintahan militer Jepang di Indonesia sangat singkat.Segala kekuasaan yang dibangun secara militer harus diserahkan kepada pasukan Sekutu. Bahkan bukan cuma senjata, tetapi tentara Jepang harus menjadi tawanan yang akan dikembalikan ke negerinya. Masa-masa inilah yang menjadi transisi bagi penguasaan Indonesia oleh negeri lain. Para tokoh pergerakan memahami betul bahwa kekalahan Jepang berarti Indonesia tidak lagi mempunyai "tuan" sehingga tiba saatnyalah untuk menjadi "tuan" di negeri sendiri. Proklamasi pun dikumandangkan, segala persiapan pemerintahan negara dirembuk dan diwujudkan, pembenahan pertahanan negara juga dibangun dengan dasar aturan yang pernah diterima dari pasukan Jepang. Seluruh lapisan rakyat siap membela kemerdekaan sehingga terbentuklah badan-badan kelasykaran dan milisi-milisi sebagai pasukan pejuang yang di antaranya memiliki tujuan tersendiri tetapi dengan satu musuh utama menghalangi Belanda kembali menjajah Indonesia.

Jika masa kekuasaan pendudukan Jepang kira-kira tiga setengah tahun, maka usaha 
pembentukan pemerintahan Republik Indonesia mulai dari proklamasi pembentukan dasar negara Pancasila (1 Juni 1945), (17 Agustus 1945), Undang Undang Dasar negara (18 Agustus 1945), pengangkatan presiden dan wakil presiden oleh KNIP (29 Agustus 1945), dan pembentukan TKR (5 Oktober 1945) hanya berlangsung selama lima bulan.

\section{DAFTAR SUMBER}

\section{Buku}

Arifin, Edy Burhan. 1996.

"Pemberontakan Peta di Blitar: Sebuah Kesaksian Sejarah". Dalam Purbo S. Suwondo (ed.). PETA Tentara Sukarela Pembela Tanah Air di Jawa dan Sumatera 1942-1945. Jakarta: Pustaka Sinar Harapan.

Asmadi, 1985.

Pelajar Pejuang. Jakarta: Sinar Harapan.

Astuti, Meta Sekar Puji. 2008. Apakah Mereka Mata-Mata? Orangorang Jepang di Indonesia (1868-1942). Yogyakarta: Ombak.

Departemen Pendidikan Nasional, 2013. Kamus Besar Bahasa Indonesia. Pusat Bahasa. Cet. VII. Edisi IV. Jakarta: Gramedia Pustaka Utama.

Gottschalk, Louis. 1986.

Understanding History : A Primer of Historical Method, atau Mengerti Sejarah, terj. Nugroho Notosusanto, Cet. V. Jakarta : UI-Press.

Hardjasaputra, A. Sobana. 2000. "Bandung", dalam Nina H. Lubis, dkk. Sejarah Kota-kota Lama di Jawa Barat. Bandung: Alqaprint.

Kuntowijoyo. 2013. Pengantar Ilmu Sejarah .Cet. I. Yogyakarta: Tiara Wacana.

Nasution. 1990.

Memenuhi Panggilan Tugas. Jilid 1: Kenangan Masa Muda. Jakarta : Masagung.

Oktorino, Nino. 2016 Di Bawah Matahari Terbit. Sejarah Pendudukan Jepang di Indonesia, 19411945. Jakarta: Elex Media Komputindo.
Onghokham. 1989.

Runtuhnya Hindia Belanda, Cetakan Kedua. Jakarta: Gramedia.

Poesponegoro, Marwati Djoened dan Nugroho Notosusanto. 1990.

Sejarah Nasional Indonesia Jilid VI.

Jakarta: Balai Pustaka.

Sjamsuddin, Helius. 2007.

Metodologi Sejarah. Edisi Revisi. Yogyakarta: Ombak.

Smail, John R.W. 2011. Bandung Awal Revolusi 1945-1946. Bandung: Ka Bandung.

Sufian, Hiroshi Maeda. 1987. Maeda Memilih Republik. Kisah Perjuangan 1945. Bandung: ITB.

Suryanegara, Ahmad Mansur. 1996. Pemberontakan Tentara PETA di Cileunca Panglengan Bandung Selatan. Jakarta: Yayasan Wira Patria Mandiri.

Wanhar, Wenri. 2014.

Jejak Intel Jepang. Kisah Pembelotan Tomegoro Yoshizumi, Jakarta: Kompas.

\section{Internet}

Bhumi Widjayakusuma. "Pemberontakan Peta di Cilacap", diakses dari http://astiannew.blogspot.co.id/2015/06/p emberontakan-peta-di-cilacap.html, tanggal 1 April 2017, pukul 08:35 wib.

Dokumens, United Nations.

"Gathering a body of global agreements", diakses dari $h t t p: / / w w w . u n-$ documents.net/gc-3.htm, tanggal 11 Januari 2017, Pukul 11:35 wib.

Hermawan, Iwan. "Bandung Sebagai Ibukota Hindia Belanda", diakses dari http://geohistori.blogspot.co.id/2010/12/b andung-sebagai-ibukota-hindia.html, tanggal 2 Maret 2016, Pukul 10.25 wib.

Sejarah dan Budaya Nusantara "Penjajahan Jepang", diakses dari http://sejarahbudayanusantara. weebly.com/jepang.html, tanggal 1 April 2017, 09.05 wib. 